\title{
PENGARUH PERKEMBANGAN PEMBANGUNAN NASIONAL SEBAGAI ASPEK PENGUBAH HUKUM DARI SEGI EKONOMI
}

\author{
Iin Indriani \\ Fakultas Hukum Universitas Pamulang \\ Email :doseno2192@unpam.ac.id
}

Received: Jul 2019/Revised: Jul 2019 / Accepted: Ags 2019

\begin{abstract}
Pembaharuan ketentuan hukum yang berlaku dipengaruhi oleh perkembangan kebutuhan masyarakat, khususnya dari segi ekonomi. Semakin tahun perekonomian semakin berkembang, perkembangan tersebut salah satunya ditentukan dari pertumbuhan investasi asing. Investasi lokal dan investasi asing menjadi suatu upaya untuk meningkatkan pembangunan nasional. Oleh sebab itu, diperlukan berbagai upaya yuridis upaya dalam mengatasi pengaruh perkembangan pembangunan nasional sebagai aspek pengubah hukum. Upaya yang dilakukan yakni disahkannya Undang-undang No. 25 Tahun 2007 Tentang Penanaman Modal dan Ketentuan hukum lainnya yang berkaitan dengan prosedur dan tata cara perizanan usaha. Hal demikian diharapkan mampu meningkatkan pembangunan nasional negara Indonesia.
\end{abstract}

Kata Kunci : Investasi, Pembangunan nasional, Pengubah hukum

\begin{abstract}
Legal provisions needed by the development of community needs, especially in terms of the economy. Increasing annual growth, this growth is one of which is determined by the growth of foreign investment. Local investment and foreign investment are places for development to increase national development. Therefore, various juridical efforts are needed in addressing the development of national development as an aspect of changing the law. Efforts made under Law No. 25 of 2007 concerning Investment and other legal provisions relating to procedures and procedures for business licensing. This is expected to increase the development of the country of Indonesia.
\end{abstract}

Keywords: Investment, national development, legal change.

\section{PENDAHULUAN}

Pembangunan bangsa Indonesia yang sedang berlangsung saat ini bertujuan untuk mencapai cita-cita bangsa Indonesia sebagaimana tercantum dalam pembukaan UUD 1945, yaitu melindungi segenap bangsa Indonesia dan seluruh tumpah darah Indonesia dan untuk mewujudkan 
kesejahteraan umum, mencerdaskan kehidupan bangsa dan turut serta menciptakan perdamaian dunia yang berdasarkan perdamaian abadi dan keadilan sosial. Pembangunan dilaksanakan dalam segala sendi-sendi kehidupan berbangsa dan bernegara secara berkelanjutan. Salah satu aspek yang menjadi sasaran pembangunan adalah aspek hukum itu sendiri.

Pembangunan hukum tersebut sangatlah dibutuhkan untuk meneruskan perjuangan bangsa merdeka setelah terlepas dari belenggu penjajahan kolonialisme barat, serta merupakan eksistensi sebagai negara yang berdaulat tentunya memerlukan kehadiran hukum nasional yang mencerminkan nilai-nilai kultur dan budaya bangsa. Pembangunan hukum pada dasarnya meliputi usaha mengadakan pembaruan pada sifat dan isi dari ketentuan hukum yang berlaku dan usaha-usaha yang diarahkan bagi pembentukan hukum baru yang diperlukan dalam pembangunan masyarakat.

Pembaharuan ketentuan hukum yang berlaku dipengaruhi oleh perkembangan kebutuhan masyarakat, khususnya dari segi ekonomi. Semakin tahun perekonomian semakin berkembang, perkembangan tersebut salah satunya ditentukan dari pertumbuhan investasi asing. Arus investasi asing bersifat fluktuatif dan sangat tergantung dari iklim investasi dari negara yang bersangkutan. Bagi negara investor sebelum melakukan investasi terlebih dahulu akan menilai terhadap aspek-aspek yang mempengaruhi iklim investasi, yaitu kesempatan ekonomi, kepastian hukum dan stabilitas politik.

Indonesia merupakan negara berkembang yang memiliki potensi yang besar sehingga banyak investor-investor baik investor lokal maupun investor asing yang berinvestasi di Indonesia. ${ }^{\mathrm{I}}$ berdasarkan hal demikian seharusnya dibutuhkan perubahan hukum, perubahan terkait aturan-aturan dalam mengatasi pengaruh perkembangan penanaman modal sebagai aspek pengubah hukum dari segi ekonomi. ${ }^{2}$

Kegiatan perubahan hukum yang sedang dilaksanakan di Indonesia mempunyai karakteristik tersendiri dan bersifat mandiri.

Perubahan itu tidak semata-mata dilakukan oleh karena hukum dirasakan kurang memadai lagi untuk mengatur kehidupan masyarakat, melainkan masyarakat Indonesia sendiri saat ini sudah mengalami perubahan yang bersifat fundamental yang bertujuan untuk menciptakan

${ }^{1}$ Suyud Margono, Hukum Investasi Asing di Indonesia, (Jakarta : Novindo Pustaka Mandiri), 2008. hal . 2

${ }^{2}$ Indriani, Iin. "PERKEMBANGAN HUKUM: PERSEROAN TERBATAS DAN PRAKTIK PENGGUNAAN NOMINEE OLEH INVESTOR ASING." PROCEEDINGS. Vol. 2. No. 1. 2017. 
masyarakat Indonesia baru sesuai dengan hukum yang hidup dalam masyarakat.

Dengan adanya perubahan tersebut, maka diharapkan pembangunan ekonomi di Indonesia dapat berjalan lebih baik, karena pembangunan dunia bisnis Indonesia mendapat tempat dan peluang yang cukup penting bagi perkembangan ekonomi, peningkatan bisnis di bidang properti, perumahan, transportasi, komunikasi dan lain-lain. Kehadiran berbagai investor bisnis lokal maupun asing dalam proses percepatan dalam berbagai aspek pembangunan ekonomi di Indonesia. Perusahaan asing dalam kegiatan investasi di Indonesia dimaksudkan sebagai pelengkap untuk mengisi sektor-sektor usaha dan industri yang belum dapat dilaksanakan sepenuhnya oleh pemerintah.

\section{PERMASALAHAN}

Sehingga timbul permasalahan yang harus di selesaikan yakni Bagaimana upaya yuridis dalam mengatasi pengaruh perkembangan pembangunan nasional sebagai aspek pengubah hukum?

\section{METODOLOGI PENELITIAN}

Penulis akan menjawab permasalahan yang timbul mengenai upaya yuridis dalam mengatasi pengaruh perkembangan pembangunan nasional sebagai aspek pengubah hukum dengan melakukan penelitian hukum (Legal Research) yakni penelitian yang didasarkan pada suatu prosedur penelitian ilmiah untuk menemukan kebenaran berdasarkan logika hukum secara normatif, logika hukum dibangun berdasarkan disiplin ilmiah dan cara kerja ilmu hukum yang obyeknya adalah ilmu hukum itu sendiri.

Dan juga mempelajari berbagai peraturan perundang-undangan hukum nasional dan kebijakan kebijakan yang dikeluarkan untuk pelaksanaan ketentuan tersebut meliputi : Undang-Undang Dasar 1945, Undang-Undang No 25 Tahun 2007 Tentang Penanaman Modal, UndangUndang No 40 Tahun 2007 Tentang Perseroan Terbatas.

\section{PEMBAHASAN}

\section{Penanaman Modal Sebagai Akibat Dari Perkembangan Pembangunan Nasional}

Indonesia sebagai suatu Negara yang mendambakan suatu masyarakat yang adil dan makmur harus selalu melakukan pembangunan berbagai bidang, diantaranya pembangunan dalam bidang ekonomi untuk menunjang segala kebutuhan dalam negeri. Pembangunan ekonomi identik 
dengan pembangunan sekor-sektor ekonomi yang terdapat di Negara itu sendiri, seperti sektor pertanian, perikanan, perternakan, pertambangan, industri, perdagangan, jasa-jasa dan lainnya. ${ }^{3}$ Konsekuensi pelaksanaan pembangunan ekonomi tersebut diperlukan adanya modal atau investasi yang besar dalam melakukan pembangunan. Dari investasi yang menunjang pembangunan ekonomi dimaksud, kemudian dikenal adanya kegiatan penanaman modal (investasi). ${ }^{4}$

Mengingat akan begitu besarnya peran penanaman modal atau investasi bagi pembangunan nasional, maka sudah sewajarnya penanaman modal atau investasi mendapat perhatian khusus dari pemerintah dan menjadi bagian yang penting dalam penyelenggaraan perekonomian nasional. Sebab dengan adanya kegiatan penanaman modal atau investasi Indonesia dapat mengolah segala potensi ekonomi yang ada menjadi kekuataan ekonomi riil. Indonesia sebagai salah satu negara yang sedang berkembang sangat membutuhkan hukum yang dapat membantu proses perubahan yang terjadi di masyarakat. Hukum sebagai sarana pembaharuan sosial harus mampu untuk memberikan pengaturan terhadap perkembangan baru. Joel B. Grossman dan Mary H. Grossman memandang hukum sebagai suatu alat yang dibutuhkan, diperlukan, dan sangat efisien untuk melakukan perubahan, yang lebih disukai daripada instrumen perubahan yang lainnya. Pembangunan hukum juga harus dapat dan mampu mengikuti perkembangan masyarakat yang sedang berkembang kearah modernisasi. Terlebih lagi pembangunan hukum harus mampu menampung semua kebutuhan pengaturan kehidupan masyarakat berdasarkan tingkat kemajuan masyarakat dalam semua bidang.

Perubahan yang teratur melalui prosedur hukum baik berwujud peraturan perundang-undangan maupun keputusan badan-badan peradilan, lebih baik daripada perubahan yang tidak teratur dengan menggunakan kekuasaan semata-mata karena baik perubahan maupun ketertiban atau keteraturan merupakan tujuan kembar dari masyarakat yang sedang membangun, hukum menjadi alat yang tidak dapat diabaikan dalam proses pembangunan. Menurut teori pembangunan, teori yang dikemukan oleh Mochtar Kusumaatmadja yaitu menurutnya hukum yang dibuat harus sesuai dan harus memerhatikan kesadaran hukum masyarakat. Hukum tidak boleh menghambat modernisasi.

3 Aminuddin Ilmar, Hukum Penanaman Modal di Indonesia, ED-1.Cet-2, (Jakarta : Kencana), 2004.hal.1

${ }^{4}$ Zainudin Ali, Aspek Hukum Penanaman Modal di Indonesia, (Jakarta : Yayasan Masyarakat Indonesia Baru), 2014. hal. 43 
Dalam era modernisasi, semakin berkembangnya globalisasi hingga memicu Indonesia untuk meningkatan perekonomiannya khususnya dalam pembangunan nasional yakni dengan membuka peluang bagi para penanam modal lokal dan asing untuk berinvestasi di Indonesia dengan harapan hal tersebut dapat memajukan kesejahteraan masyarakat. Menurut Charles Himawan ${ }^{5}$ Indonesia merupakan negara yang kaya yang membuat investor asing ingin menanamkan modalnya di Indonesia, hal ini semacam myth di dunia penanaman modal global. Oleh karena itu sangat diperlukan peraturan perundang-undangan yang memberikan kepastian hukum terhadap investor asing dan juga memberikan perlindungan terhadap kehidupan masyarakat Indonesia. Penanaman modal asing pada setiap negara mempunyai peran penting yaitu sebagai salah satu sumber penggerak pembangunan ekonomi, selain itu sebagai sumber penting peralihan teknologi dan knowledge lainnya. Peran dimaksud, dapat ditempuh melalui dua jalur utama yaitu : ${ }^{6}$ Pertama, lewat pekerja-pekerja lokal yang bekerja di perusahaan-perusahaan PMA. Saat pekerja-pekerja tersebut pindah ke perusahaan-perusahaan domestik, maka mereka membawa pengetahuan atau keahlian baru dari perusahaan penanaman modal asing ke perusahaan domestik. Hal dimaksud, sudah mentransfer pengetahuannya ke tempat bekerja di perusahaan domestik. Kedua, lewat keterkaitan produksi atau subcontracting antara perusahaan penanaman modal asing dengan perusahaan-perusahaan lokal, termasuk usaha kecil dan menengah juga akan membawa pengetahuan atau keahlian baru bagi tenaga kerja di perusahaan lokal, baik di perusahaan kecil maupun di perusahaan menegah (UKM).

Modal asing juga diharapkan secara langsung maupun tidak langsung dapat merangsang dan menggairahkan kehidupan dunia usaha, serta dapat dimanfaatkan sebagai upaya menebus jaringan pemasaran internasional melalui jaringan yang mereka miliki. Selanjutnya modal asing diharapkan secara langsung mempercepat proses pembangunan ekonomi Indonesia.

Pembahasan mengenai latar belakang investasi, khususnya penanaman modal asing di Indonesia, berkaitan erat dengan sejarah peraturan perundang-undangan bidang penanaman modal asing yang pengaturannya sudah sejak lama mendapatkan perhatian dari pemerintah, jauh sebelum masa orde baru. Namun hal tersebut belum dapat terlaksana

${ }^{5}$ Charles Himawan, The Foreign Investment Process In Indonesia, (Jakarta, PT. Gunung Agung), 1980. hal. 4

${ }^{6}$ Ibid, 60-61 
karena pada masa itu berkembang anggapan bahwa masuknya modal asing justru akan menghambat pertumbuhan ekonomi rakyat karena akan memeras bangsa dan sumber-sumber kekayaan alam Indonesia.

Tetapi seiring dengan perkembangan jaman, adanya globalisasi khususnya dalam bidang ekonomi mengakibatkan pengaruh terhadap perkembangan pembangunan nasional sebagai aspek pengubah hukum. Hal ini disebabkan oleh maraknya penanaman modal di Indonesia, penanaman modal dianggap mampu memberikan konstribusi untuk memperkuat struktur perekonomian nasional. Oleh karena itu dengan latar belakang tersebut, pemerintah melakukan perubahan hukum yakni dengan membuat aturan-aturan yang mengatur hal-hal terkait demi memberikan kepastian hukum, umumnya bagi masyarakat atau penanam modal dalam negeri serta khususnya bagi penanam modal asing. Hingga perubahan tersebut dapat memberikan perubahan yang terbaik bagi semua pihak. Hal ini sesuai dengan Teori Sociological, Eugen Ehrlich yang berpendapat bahwa hukum positif akan memiliki daya berlaku yang efektif apabila berisikan atau selaras dengan hukum yang hidup dalam masyarakat.

\section{Produk Hukum Dalam Mengatasi Perkembangan Pembangunan Nasional}

Sunaryati Hartono dalam bukunya mengemukakan bahwa prinsip utama dalam kebijaksanaan ekonomi pemerintah Indonesia terletak pada kesempatan serta kesanggupan rakyat Indonesia sendiri (swadaya) untuk pembangunan ekonomi nasionalnya. ${ }^{7} \mathrm{Hal}$ mana tidak berarti bahwa secara apriori pemerintah harus menolak modal, teknologi dan bantuan luar negeri untuk ikut serta dalam pembangunan ekonomi nasional kita, selama partisipasi modal dan bantuan luar negeri itu dapat diabadikan kepada pembangunan ekonomi kita serta tidak merugikan pembangunan ekonomi nasional.

Prof. Erman Rajagukguk juga mengemukakan bahwa pemerintah orde baru di bawah pimpinan Presiden Soeharto menyadari sejak semula bahwa bantuan asing, baik berupa bantuan teknik maupun modal bukan merupakan faktor yang menentukan berhasilnya pembangunan ekonomi di Indonesia. Namun peranan bantuan tersebut dalam masa transisi untuk memulihkan lagi ekonomi Indonesia telah diakui sebagai hal yang sangat penting. ${ }^{8}$

${ }^{7}$ Sunaryati Hartono, Beberapa Masalah Transnasional Dalam Penanaman Modal Asing Di Indonesia, (Bandung: Binacipta,) 1979. hal. 30

${ }^{8}$ Erman Rajagukguk, Indonesianisasi Saham, (Jakarta, Rineka Cipta), 1985. hal. 1 
Setiap usaha penanaman investasi harus diarahkan kepada kesejahteraan masyarakat. Artinya, dengan adanya investasi yang ditanamkan para investor dapat meningkatkan kualitas masyarakat Indonesia. Di Indonesia sendiri, konsep kesejahteraan merujuk kepada konsep pembangunan kesejahteraan sosail, yakni serangkaian aktifitas yang terencana dan melembaga yang ditujukan untuk meningkatkan standar dan kualitas kehidupan manusia. Dengan didasarkan kepada konsep Negara kesejahteraan melalui pembangunan ekonomi, dalam rangka mewujudkan dan meningkatkan kesejahteraan, percepatan, peningkatan, dan pembangunan ekonomi harus dilakukan melalui pembangunan ekonomi nasional yang sejalan dengan konstitusi Negara yang telah mengamanatkan agar pembangunan ekonomi nasional harus berdasarkan prinsip demokrasi yang mampu menciptakan terwujudnya kedaulatan ekonomi Indonesia.

Pembangunan ekonomi yang berlandaskan prinsip demokratis tersebut merupakan perwujudan ekonomi kerakyatan sebagaimana ketentuan padal 33 Undang-Undang Dasar 1945 yang merupakan landasan filosofis yang menjadi acuan pemberlakuan Undang-Undang No 25 Tahun 2007. Penanaman modal atau investasi merupakan pilar penting dalam pertumbuhan ekonomi suatu Negara karena ekonomi Negara yang hendak tumbuh berkelanjutan membutuhkan modal terus-menerus. Dengan pendapatan per kapita yang rendah, Indonesia memupuk modal dengan kecepatan tinggi untuk mengejar ekonomi yang berpendapatan lebih tinggi. Kebutuhan akan modal secara terus-menerus hanya dapat dipenuhi apabila faktor penunjang yang menghambat iklim penanaman modal dapat diatasi, seperti dengan melakukan perbaikan koordinasi antar instansi pemerintah pusat dan daerah, penciptaan birokrasi yang efesien kepastian hukum di bidang penanaman modal, biaya ekonomi yang berdaya saing tinggi serta iklim usaha yang kondusif di bidang ketenangankerjaan dan keamanan berusaha.

Dengan adanya perbaikan di bidang-bidang tersebut maka harapan untuk mendapatkan modal secara terus-menerus akan dapat terealisasikan. Untuk itu dalam kaitannya dengan penanaman modal, perlu dan patut ditonjolkan beberapa perubahan mendasar yang bermuara pada peninggian mobilitas. Kebijakan penanaman modal yang mengandung pembatasanpembatasan ketat dan merupakan praktik luas hampir di semua Negara berkembang harus diganti dengan kebijakan penanaman modal yang lebih terbuka. Nondiskriminasi dan perlakuan yang sama bagi modal dalam negeri dan modal asing diterima sebagai salah satu asas penting dalam kebijakan penanaman modal dan juga Perampingan daftar negatif 
penanaman modal sebagai salah satu kebijakan yang dapat mendorong majunya penanaman modal. Kebijakan penanaman modal Indonesia harus diharmoniskan dengan perubahan-perubahan besar melalui deregulasi yang bersifat pragmatik.

Oleh karena itu, Undang-Undang Penanaman Modal harus mengatur hal hak penting, antara lain seperti semua hal yang berkaitan dengan kegiatan penanaman modal langsung di semua sektor yang meliputi kebijakan dasar penanaman modal, bentuk keterkaitan pembangunan ekonomi dengan pelaku ekonomi yang diwujudkan dengan pengaturan mengenai pengembangan penanaman modal dan tanggung jawab penanaman modal serta fasilitas penanaman modal, pengesahan dan perizinan koordinari dan pelaksanaan kebijakan penanaman modal yang didalamnya mengatur mengenai kelembagaan urusan penanaman modal dan ketentuan yang mengatur tentang penyelesaian sengketa. ${ }^{9}$ Karena pada prinsipnya para pemilik modal menginginkan suatu kemudahan dalam melakukan usahanya, mengakibatkan persaingan diantara negara-negara berkembanga untuk menarik penanam modal, sehingga tiap Negara berlomba memberikan kemudahan bagi para penanaman modal yang diwujudkan dalam bentuk undang-undang ataupun kebijakan pemerintah sebagai bentuk kepastian hukum bagi para penanam modal.

Selanjutnya, fasilitas penanaman modal diberikan dengan mempertimbangkan tingkat daya asing perekonomian dan kondisi keuangan Negara dan harus promotif dibandingkan dengan fasilitas yang diberikan oleh Negara lain. Pentingnya kepastian fasilitas penanaman modal ini mengharuskan pengaturan yang lebih detail terhadap bentuk fasilitas fiskal, fasilitas hak atas tanah, imigrasi dna fasilitas perizinan impor. Dengan demikian, Undang-Undang Penanaman Modal harus mampu mengakomodasi persaingan, oleh karena itu Undang-Undang Penanaman Modal yang selama ini menjadi dasar hukum kegiatan penanaman modal di Indonesia perlu diganti karena tidak sesuai lagi dengan tantangan kebutuhan untuk mempercepat perkembangan perekonomian nasional melalui konstruksi pembangunan hukum nasional dibidang penanaman modal yang berdaya saing dan berpihak kepada kepentingan nasional.

Pemberlakuan Undang-Undang Nomor 25 Tahun 2007 tentang Penanaman Modal sebagai pengganti Undang-Undang Nomor I Tahun 1967 tentang Penanaman Modal Asing jo Undang-Undang Nomor II

${ }^{9}$ Iqbal, Muhamad. "IMPLEMENTASI EFEKTIFITAS ASAS OPORTUNITAS DI INDONESIA DENGAN LANDASAN KEPENTINGAN UMUM." Jurnal Surya Kencana Satu: Dinamika Masalah Hukum dan Keadilan 9.1 (2018). 
Iin Indriani

Tahun 1970 tentang Perubahan dan Tambahan Undang-Undang Nomor I Tahun 1967 tentang Penanaman Modal Asing dan Undang-Undang Nomor 6 Tahun 1968 tentang Penanaman Modal Dalam Negeri jo Undang-Undang Nomor 12 Tahun 1970 tentang Perubahan dan Tambahan Undang-Undang Nomor 6 Tahun 1968 tentang Penanaman Modal Dalam Negeri tentunya mempunyai makna bahwa undang-undang sebelumnya tidak relevan lagi untuk menjawab persaingan yang saling tarik-menarik untuk memperebutkan penanam modal diantara Negara-negara berkembang.

Tentunya dengan pemberlakuan Undang-Undang Nomor 25 Tahun 2007 tentang Penanaman Modal sebagai suatu bentuk penyempurnaan dari undang-undang sebelumnya mampu menjawab tantangan persaingan yang slaing tarik-menarik untuk memperebutkan penanam modal diantara Negara-negara berkembang yaitu dengan memberikan kepastian hukum serta kebijakan penanaman modal yang tepat. Pertam, Kepastian Hukum Dalam kaitannya dengan memberikan kepastian hukum kepada para penananm modal, Undang-Undang Nomor 25 Tahun 2007 tentang Penanaman Modal memperlakukan para penanam modal baik itu pemodal dalam negri maupun pemodal dalam negeri maupun pemodal asing dengan perlakuan yang sama secara hukum, karena undang-undang sebelumnya tiap-tiap penanam modal diatur dengan dua undang-undang yang berbeda yaitu antara penanam modal asing dan penanam modal dalam negeri, hal ini mengakibatkan timbulnya anggapan adanya dualisme hukum yang mengatur tentang penanaman modal, akhirnya timbul suatu anggapan bahwa insentif-insentif yang diberikan oleh pemerintah atau Negara tidak berlaku secara menyeluruh kepada setiap penanam modal, sehingga perlu adanya klasifikasi oleh para penanam modal untuk menentukan mana insentif yang berlaku untuk pemodal asing dan mana insentif yang berlaku untuk pemodal dalam negeri, namun kemudian dengan adanya pemberlakuan Undang-Undang tentang Penanaman Modal yang baru kepastian hukum dapat diberikan kepada penanam modal, bawah fasilitasfasilitas ataupun insentif-insentif yang diberikan oleh pemerintah berlaku bagi setiap penanam modal bilamana para penanam modal tersebut memenuhi persyaratan yang telah ditentukan oleh undang-undang. Selain memberikan kepastian hukum pada wilayah perlakuan yang sama secara hukum kepada setiap penanam modal Undang-Undang Nomor 25 Tahun 2007 tentang Penanam Modal juga memberikan jaminan kepada para penanam modal bahwa pemerintah tidak akan melakukan nasionalisasi, walaupun undang-undang lama juga mengatur tentang nasionalisasi dan kompensansi namun masih ada kekhawatiran bagi investor tentang kata- 
kata “... Pencabutan hak kepemilikan secara menyeluruh atas perusahaanperusahaan modal asing ...”, artinya kepastian tentang tidak hanya nasionalisasi belum secara tegas disebutkan dalam undang-undang lama, sementara dalam Undang-Undang Nomor 25 Tahun 2007 tentang Penanaman Modal disebutkan secara tegas bahwa pemerintah tidak akan melakukan nasionalisasi kecuali dengan undang-undnag sebagaimana disebutkan dalam Pasal 7 ayat (I) Undang-Undang no 25 Tahun 2007. Aturan mengenai bentuk kompensasi yang dibeirkan pemerintah kepada penanam modal pun berbeda dalam Undang-Undang Nomor I Tahun 1967 diatur bahwa bentuk kompensasi yang diberikannya belum tegas terganutng dari kesepakatan antara kedua belah pihak menurut asas-asas hkum internasional, sementara Undang-Undang Nomor 25 Tahun 2007 sudah mengatur dengan tegas bahwa kompensasi yang akan diberikan sesuai dengan harga pasar, dengan begitu baik penanam modal maupun pemerintah tidak akan ada yang dirugikan. Undang-Undang Nomor 25 Tahun 2007 tentang Penanam Modal juga memberikan kebebasan kepada penanam modal untuk mengalihkan aset yang dimilikinya kepada pihak yang dikehendakinya sesuai dengan Undang-Undang.

Kedua, Kebijakan Penanaman Modal Yang Tepat Dalam UndangUndang Nomor 25 Tahun 2007 tentang Penanaman Modal mengalami perluasan makna tentang definisi modal itu sendiri, bahwa yang dimaksud dalam modal tidak hanya mencangkup valuta asing, alat-alat produksi dan penanam namun juga mencangkup modal portofolio, Undang-Undang Nomor 25 Tahun 2007 juga memberikan kebijakan izin penanaman modal kepada penanam modal untuk menanamkan modalanya tanpa adanya batas waktu selama memenuhi peraturan perundang undangan sementara dalam Undang-Undang Nomor I Tahun 1967 pemerintah hanya memberikan izin selama 30 Tahun.

Kebijakan pemberian izin kepada para penanam modal dalam jangka waktu yang tak terbatas tentunya dapat menambah minat kepada para penanam modal untuk menanamkan modalnya di Indonesia terlebih lagi dengan adanya daftar negatif yang sangat pendek yang diberikan oleh Undang-Undnag Nomor 25 Tahun 2007 membuka lebih banyak lagi ruangruang berusaha bagi para penanam modal.

Hal demikian juga sesuai dengan Teori Modern Sociological Theory yang dikemukan oleh Talcott Parsons yaitu ekonomi merupakan institusi adaptif yang utama pada tingkat organisasi sistem sosial. ${ }^{\text {10 }}$ Dapat

${ }^{10}$ Bernard.L.Tanya, dkk, Teori Hukum (Strategi Tertib Manusia Lintas Ruang dan Waktu ,(Yogyakarta: Genta Publishing), 2010. hal.152-153 
diasumsikan bahwa kekuatan penggerak utama yang mendorong pembangunan sistem hukum di dalam masyarakat datang dari bidang ekonomi. Segera setelah perekonomian mampu untuk menghasilkan surplus produksi yang melampaui kebutuhan, maka banyak terjadi pertukaran barang-barang. Hukum menjadi faktor pengintegrasi.

Seiring dengan pemberlakuan Undang-undang Penanaman Modal sejak tahun 2007 lalu hingga sampai saat ini, memberikan pengaruh yang besar terhadap peningkatan investasi yang berimplikasi pada pembangunan nasional di Indonesia. Investasi diharapkan dapat meningkatkan ekonomi di Indonesia pada tahun ini. Dan juga secara khusus memiliki peran perkembangan terkait teknologi terhadap daya saing industri nasional. Namun karena lemahnya birokasi dan adanya celah hukum dalam berbagai perizinan segala sektor. Hal ini menjadi masalah dalam meningkatkan pembangunan nasional.

\section{KESIMPULAN}

I. Perkembangan pembangunan nasional sebagai aspek pengubah hukum dari segi ekonomi mempengaruhi perkembangan penanaman modal di Indonesia. Hal demikian terjadi karena penanaman modal dianggap mampu memberikan konstribusi untuk memperkuat struktur perekonomian nasional. Oleh karena itu dengan latar belakang tersebut, pemerintah melakukan perubahan hukum yakni dengan membuat aturan-aturan yang mengatur hal-hal terkait demi memberikan kepastian hukum kepada penanam modal, agar mempercepat perkembangan perekonomian nasional melalui konstruksi pembangunan hukum nasional dibidang penanaman modal yang berdaya saing dan berpihak kepada kepentingan nasional

2. Upaya yuridis untuk mengatasi pengaruh perkembangan pembangunan nasional sebagai aspek pengubah dari segi ekonomi yaitu dengan disahkannya Undang-Undang No. 25 Tahun 2007 Tentang Penanaman Modal yang menggantikan Undang-Undang PMA dan Undang-Undang PMDN sebelumnya, hal ini dikarenakan Undang-Undang sebelumnya dianggap tidak relevan lagi dengan kondisi globalisasi yang semakin berkembang. Hingga membuat pemerintah Indonesia merasa harus membuat aturan-aturan baru serta ketentuan hukum lainnya yang diharapkan dapat memberikan perubahan khususnya bagi pembangunan perekonomian nasional. 
Abdul Manan, Aspek-Aspek Pengubah Hukum, Kencana, Jakarta, 2006. Aminuddin Ilmar, Hukum Penanaman Modal di Indonesia, Prenada

Media Group, Jakarta, 2007.

Bernard.L.Tanya, dkk, Teori Hukum (Strategi Tertib Manusia Lintas

Ruang dan Waktu), Genta Publishing, Yogyakarta, 2010.

Charles Himawan, The Foreign Investment Process in Indonesia, PT.

Gunung Agung, Jakarta, 1980.

Erman Rajagukguk, Indonesianisasi Saham, Rineka Cipta, Jakarta, 1985.

Iqbal, Muhamad. "IMPLEMENTASI EFEKTIFITAS ASAS OPORTUNITAS DI INDONESIA DENGAN LANDASAN KEPENTINGAN UMUM."Jurnal Surya Kencana Satu: Dinamika Masalah Hukum dan Keadilan 9.I (2018).

Indriani, Iin. "PERKEMBANGAN HUKUM: PERSEROAN TERBATAS DAN PRAKTIK PENGGUNAAN NOMINEE OLEH INVESTOR ASING." PROCEEDINGS. Vol. 2. No. 1. 2017.

Suyud Margono, Hukum Investasi Asing di Indonesia, Novindo Pustaka Mandiri, Jakarta, 2008.

Sunaryati Hartono, Beberapa Masalah Transnasional Dalam Penanaman Modal Asing di Indonesia, Binacipta, Bandung, 1979.

Zainudin Ali, Aspek Hukum Penanaman Modal di Indonesia, Yayasan Masyarakat Indonesia Baru, Jakarta, 2014. 

